\title{
A study on faeto-maternal outcome in pregnancy with jaundice due to hepatitis $\mathrm{E}$
}

\author{
Sushanta Kumar Jena ${ }^{1 *}$, Minakshi Mohanty ${ }^{2}$, Sasmita Behuria $^{3}$
}

\begin{abstract}
${ }^{1}$ Department of Hepatology, Shri Ramachandra Bhanj Medical College, Cuttack, Odisha, India
${ }^{2}$ Department of Community Medicine, Shri Ramachandra Bhanj Medical College, Cuttack, Odisha, India

${ }^{3}$ Department of Obstetrics and Gynaecology, Shri Ramachandra Bhanj Medical College, Cuttack, Odisha, India
\end{abstract}

Received: 17 January 2017

Revised: 18 January 2017

Accepted: 30 January 2017

\section{*Correspondence: \\ Dr. Sushanta Kumar Jena, \\ E-mail: drskjena07@gmail.com}

Copyright: () the author(s), publisher and licensee Medip Academy. This is an open-access article distributed under the terms of the Creative Commons Attribution Non-Commercial License, which permits unrestricted non-commercial use, distribution, and reproduction in any medium, provided the original work is properly cited.

\begin{abstract}
Background: Hepatitis E virus is a non-envelope RNA virus responsible for large epidemics in Asia, the Middle east Mexico and Africa. It spreads via the feco-oral route, and has an incubation period of 8-10 weeks. The objective of the study was to find out the effect of hepatitis E during pregnancy on faeto-maternal outcome.

Methods: A study on faeto-maternal outcome of 38 pregnant women admitted with jaundice due to hepatitis $E$ to the Department of Hepatology, Shri Ramachandra Bhanj (SCB) Medical College, Cuttack, Odisha, India during January 2015 to December 2015.

Results: 38 Pregnant women admitted to the Department of Hepatology of SCB Medical College, Cuttack, Odisha, India were studied. $65.7 \%$ were from rural area, $92.1 \%$ were in their third trimester of pregnancy. Serum bilirubin $>10$ $\mathrm{mg}$ in $52.19 \%$, SGOT, SGPT and alkaline phosphatase were raised in majority of them. Out of 38 women 32 delivered and 6 remain undelivered. In $81.25 \%$ of cases labor was spontaneous, perinatal mortality was observed in $46.87 \%$ of cases and 5 women died during child birth.

Conclusions: When pregnancy is associated with jaundice due to hepatitis E, there is high perinatal and maternal morbidity and mortality. Early diagnosis and careful management is required for such cases.
\end{abstract}

Keywords: Hepatitis E, Jaundice in pregnancy

\section{INTRODUCTION}

Hepatitis E virus is a non-envelope RNA virus responsible for large epidemics in Asia, the Middle east Mexico and Africa. It spreads via the feco-oral route, and has an incubation period of $8-10$ weeks. The infection is usually self-limited and does not result in chronic disease. The incidence of acute viral hepatitis $\mathrm{E}$ is identical in pregnant and non-pregnant persons. However, pregnant women are at high risk for acute and fulminant hepatitis. Mortality rate in pregnancy can reach $25 \%$ whereas it is $0.65 \%$ non-pregnant women. ${ }^{1} \mathrm{HEV}$ infection occurs in the late stages of pregnancy, mortality is at its highest. Vertical transmission to the new-born occurs in $50 \%$ if mothers are positive for HEV PCR at the time of delivery. Premature deliveries, miscarriages and stillbirths have been reported. ${ }^{2}$ Jaundice in pregnancy is an important medical disorder seen more often in developing countries than in developed ones. It could be peculiar to the pregnancy viz., acute fatty liver of pregnancy, recurrent cholestatic jaundice in pregnancy and jaundice complicating toxaemia of pregnancy. ${ }^{3}$

\section{METHODS}

38 pregnant women with jaundice due to HEV who were admitted to the hepatology ward of SCB Medical College, Cuttack, Odisha, India were taken as study 
subject. Time period of study was from January 2015 to December 2015.

A detail history was taken and general systemic examinations were carried out. Investigation included liver function test (LFT) serum bilirubin, SGOT, SGPT, Alkaline Phosphatase, Australia antigen, HCV, HEV, HAV, prothrombin time (PT), partial thromboplastin time (PTT), bleeding time (BT), Clotting Time (CT) and platelet court which were carried out as and when required. These patients were followed up in the Obstetrics and Gynaecology Department of SCB Medical College, Cuttack, Odisha, India for feto-maternal outcome.

\section{RESULTS}

In present study $65.7 \%$ of women were from rural area and $34.3 \%$ of women from urban area. $81.57 \%$ of women were either primigravidas or second gravidas. $84.21 \%$ of the women were between 20-30 years of age. The findings of the study are similar to study by Tripti $\mathrm{N}$ et al $92.1 \%$ of patient were in third trimester of pregnancy. ${ }^{3}$

Table 1: Clinical presentation at the time of admission $(n=38)$.

\begin{tabular}{|lll|}
\hline Clinical presentation & Number & Percent \\
\hline Nausea & 30 & 78.95 \\
\hline Vomiting & 15 & 39.47 \\
\hline Loss of appetite & 30 & 78.95 \\
\hline Yellow discoloration of urine & 38 & 100 \\
\hline Hematemesis & 1 & 2.63 \\
\hline Pain in abdomen & 29 & 76.32 \\
\hline Pallor & 10 & 26.32 \\
\hline Icterus & 38 & 100 \\
\hline Hepatomegaly & 3 & 7.89 \\
\hline Splenomegaly & 2 & 5.26 \\
\hline Abdominal tenderness & 6 & 15.79 \\
\hline Edema & 18 & 47.37 \\
\hline Patechie & 2 & 5.26 \\
\hline Vaginal bleeding & 3 & 7.89 \\
\hline Preeclampsis & 14 & 36.84 \\
\hline Shock & 1 & 2.63 \\
\hline
\end{tabular}

\section{Pregnancy outcome}

32 out of 38 patients delivered while 6 remain undelivered.

\section{Maternal complication}

$5(13.16 \%)$ women died. Hepatic encephalopathy was present $8(21.05 \%)$ cases. Renal failure was seen in 5 $(13.16 \%)$ patients and $2(5.26 \%)$ patients suffered postpartum haemorrhage.
Table 2: Results of investigations $(n=38)$.

\begin{tabular}{|lll|}
\hline Investigation & Number & Percent \\
\hline Serum bilirubin & \multicolumn{2}{l|}{} \\
\hline$<10 \mathrm{mg} \%$ & 22 & 57.89 \\
\hline $10-15 \mathrm{mg} \%$ & 8 & 21.05 \\
\hline $15-20 \mathrm{mg} \%$ & 7 & 18.42 \\
\hline$>20 \mathrm{mg} \%$ & 1 & 2.63 \\
\hline SGOT and SGPT & & \\
\hline$<100 \mathrm{IU} / \mathrm{mL}$ & 13 & 34.21 \\
\hline$>100-500 \mathrm{IU} / \mathrm{mL}$ & 16 & 42.11 \\
\hline$>500-1000 \mathrm{IU} / \mathrm{mL}$ & 6 & 15.79 \\
\hline$>1000 \mathrm{IU} / \mathrm{mL}$ & 3 & 7.89 \\
\hline Alkaline phosphatase raised & 18 & 47.37 \\
\hline
\end{tabular}

Table 3: Pregnancy outcome $(n=38)$.

\begin{tabular}{|lll|}
\hline Outcome & Number & Percent \\
\hline Mode of delivery & $32 / 38$ & 84.29 \\
\hline Vaginal & $26 / 32$ & 81.25 \\
\hline Forceps & $2 / 32$ & 6.25 \\
\hline Cesarean section & $4 / 32$ & 12.50 \\
\hline Undelivered & $6 / 38$ & 15.79 \\
\hline Aborted & $1 / 38$ & 2.63 \\
\hline Death & $5 / 38$ & 13.16 \\
\hline
\end{tabular}

\section{Fetal outcome}

Out of 32 delivery $20(62.5 \%)$ were born alive and 12 (37.5\%) still born. Early neonatal death was $9.37 \%$ (3/32) and total perinatal death was $46.87 \%(15 / 32)$.

Table 4: Perinatal outcome $(n=32)$.

\begin{tabular}{|lll|}
\hline Outcome & Number & Percent \\
\hline Born alive & $20 / 32$ & 62.5 \\
\hline Still born & $12 / 32$ & 37.5 \\
\hline Early neonatal death & $3 / 32$ & 9.37 \\
\hline Total perinatal death & $15 / 32$ & 46.87 \\
\hline
\end{tabular}

Table 5: Maternal complications $(n=38)$.

\begin{tabular}{|lll|}
\hline Complication & Number & Percent \\
\hline Encephalopathy & 8 & 21.05 \\
\hline $\begin{array}{l}\text { Disseminated intravascular } \\
\text { coagulation }\end{array}$ & 6 & 15.79 \\
\hline Renal failure & 5 & 13.16 \\
\hline Eclampsia & 5 & 13.16 \\
\hline Postpartum hemorrhage & 2 & 5.26 \\
\hline Shock & 1 & 2.63 \\
\hline Death & 5 & 13.16 \\
\hline
\end{tabular}

\section{DISCUSSION}

Jaundice occurring in pregnancy can be due to hepatitis of $\mathrm{A}, \mathrm{B}, \mathrm{C}, \mathrm{D}$ or $\mathrm{E}$ type. Cholestatic jaundice is also common during pregnancy. $\mathrm{HEV}$ in pregnancy is 
associated with high maternal and perinatal mortality rates. Our perinatal mortality rate was $46.87 \%$ (Table 4). High perinatal mortality rate of $45.45 \%$ was observed by Singh et al. $^{4}$ In another study by Khuroo MS et al acute hepatitis $\mathrm{E}$ during the third trimester of pregnancy is a cause of fulminant hepatic failure and has a mortality rate of up to $20 \% .^{5}$ The risks of intrauterine death and abortion in any trimester are greater in pregnant women with hepatitis $\mathrm{E}$ than they are in their uninfected counterparts by Jain RK et al. ${ }^{6}$

Our maternal mortality was $13.16 \%$ (5/38). A similar high mortality it reported by various authors. Kamalajayaram and Rama Devi reported 33.3\% maternal mortality and Singh et al reported $10 \% .{ }^{4,7}$ In a study by Sarin SK et al the maternal mortality was due to HEV in pregnancy was $41 \% .^{8}$ Hepatorenal failure, encephalopathy. DIC and postpartum hemorrhage were responsible for the deaths.

\section{CONCLUSION}

The factors responsible for a high maternal mortality in our country may be poor nutrition, prevalence of anemia, delay in seeking medical advice, and delay in referral to the hospital. Many of the patients when brought to the hospital are already in moribund condition and often, do not respond to treatment

Funding: No funding sources Conflict of interest: None declared

Ethical approval: The study was approved by the Institutional Ethics Committee

\section{REFERENCES}

1. Mitra AK, Patki PS, Mitra SK. Liver disorders during pregnancy and their management, The antiseptic 2008;105(4):193-196.

2. Kumar A, Agarwal R. Immunological alternations in pregnant women with acute hepatitis E. J Gastroenterol Hepatol. 2005;20:1094-1101.

3. Nagaria T, Agarwal S. Fetomaternal outcome in jaundice during pregnancy. J Obstet Gynecol India. 2005;55(5):424-7.

4. Singh S, Chauhan R, Patel RS. Jaundice in pregnancy. J Obstet Gynecol India. 1991;41:187-9.

5. Khuroo MS, Teli MR, Skidmore S. Incidence and severity of viral hepatitis in pregnancy. Am J Med. 1981;70:252.

6. Jain RK. Management of Jaundice in pregnancy; Medicine update 2010;20:470-6.

7. Kamalajayaram V, Rama Devi A. A study of maternal mortality in jaundice. J Obstet Gynecol India. 1988;38:439-41.

8. Patra S, Kumar A, Trivedi SS, Puri M, Sarin SK Maternal and fetal outcomes in pregnant women with acute hepatitis E virus infection; Ann Intern Med. 2007;147:28-33.

Cite this article as: Jena SK, Mohanty M, Behuria S. A study on faeto-maternal outcome in pregnancy with jaundice due to hepatitis E. Int J Reprod Contracept Obstet Gynecol 2017;6:861-3. 